\title{
Metal effects on histological and biochemical parameters of common rudd (Scardinius erythrophthalmus L.)
}

\author{
Elenka Georgieva, Stela Stoyanova, Iliana Velcheva, Tonka Vasileva, Veselin Bivolarski, \\ Ilia Iliev, Vesela Yancheva
}

Received - 25 February 2014/Accepted - 09 July 2014. Published online: 30 September 2014; Inland Fisheries Institute in Olsztyn, Poland Citation: Georgieva E., Stoyanova S., Velcheva I., Vasileva T., Bivolarski V., Iliev I., Yancheva V. 2014 - Metal effects on histological and biochemical parameters of common rudd (Scardinius erythrophthalmus L.) - Arch. Pol. Fish. 22: 197-206.

\begin{abstract}
The present study aimed to evaluate the current contamination status of Topolnitsa Reservoir, which is located in a region with intensive copper mining. The reservoir has been continually contaminated with metals over the last few decades. As, $\mathrm{Cd}, \mathrm{Cu}, \mathrm{Ni}, \mathrm{Pb}$, and $\mathrm{Zn}$ concentrations were measured in surface water samples and in the liver of common rudd, Scardinius erythrophthalmus (L.), in three different seasons: spring, summer, and autumn. The morphological structure of the fish liver was examined and the hepatic LDH, ALAT, and ASAT activities were measured. In general, metal concentrations in the water varied, but $\mathrm{As}$ and $\mathrm{Cu}$ were present in all three seasons at levels higher than the maximum permissible levels set by law. The metal concentrations in the fish liver were significantly higher than in the water. Histological alterations were classified as degenerative changes (granular, vacuolar, hydropic, and fatty degeneration), necrotic changes (necrobiosis) - karyopyknosis, karryorehsis, and karyolyzis, and necrosis)); and changes in blood vessels (hyperemia in sinusoids and major blood vessels). Higher LDH, ALAT, and ASAT activities in fish livers were measured in
\end{abstract}

\section{E. Georgieva}

Department of Developmental Biology, Faculty of Biology, Plovdiv

University, Bulgaria

S. Stoyanova [\$], I. Velcheva, V. Yancheva

Department of Ecology and Conservation of Nature

Faculty of Biology, Plovdiv University, Bulgaria

24, Tzar Asen, St., 4000, Plovdiv, Bulgaria

Tel.: +35932261513; e-mail: stela.st@abv.bg

\section{T. Vasileva, V. Bivolarski, I. Iliev}

Department of Biochemistry and Microbiology, Faculty of Biology,

Plovdiv University, Bulgaria comparison to reference fish. In addition, the ALAT activity in the livers of $S$. erythrophthalmus from Topolnitsa Reservoir was significantly higher in the summer. Overall, it can be concluded that the metal-contaminated waters of Topolnitsa Reservoir lead to negative changes in the common rudd tissues at the cellular level including impaired structure and enhanced enzymatic activity in the fish liver.

Keywords: metals, fish, liver, histology, enzymes

\section{Introduction}

Contamination with metals from mining and smelting operations poses serious threats to aquatic environments because of its toxicity, persistence, bioaccumulation, and biomagnification in the food chain (Mohamaddi et al. 2011). Under certain environmental conditions (e.g., water temperature, $\mathrm{pH}$, hardness, and river flow) and biotic factors (e.g., organism life-history traits) they can accumulate to toxic concentrations and cause ecological damage (Chahid et al. 2014). Fish are sentinel organisms in aquatic ecosystems, and they are also considered to be the most readily usable organisms in environmental health assessments. They are preferred in toxicological research because of their well-developed osmoregulatory, endocrine, nervous, and immune systems (Song et al. 2012). Numerous studies have 
quantified contaminants in fish organs to evaluate environmental quality, seeking causal relationships with fish health, and, based on these, the liver is likely to be the best choice, followed by the kidney and gills (Pokorska et al. 2012, Majnoni et al. 2013). Histological alterations in the selected target organs are sensitive biomarkers for metal pollution, occur earlier, and provide for a better evaluation of the effects of pollution than any single biochemical parameter (Poleksić et al. 2010). Antioxidant enzymes are also considered to be sensitive biomarkers, and they are important parameters for testing water quality and the negative effects of metals on fish (Hansen et al. 2006). Thus, various responses of enzymes have been observed in animals exposed to metal contaminants in both field and laboratory experiments, which indicated an increase or decrease in activity depending on the dose, species, and route of exposure (Cao et al. 2010).

Topolnitsa Reservoir is located on the Balkan Peninsula of west central Bulgaria in a region that is rich in copper ores. Over the last few decades, intense copper mining and smelting processes have had a great impact on water ecosystems. Industrial effluents (loaded with $\mathrm{As}, \mathrm{Cd}, \mathrm{Cu}, \mathrm{Ni}, \mathrm{Pb}, \mathrm{Zn}$, etc.) have been continually released into the major north tributaries of the Topolnitsa River and the Zlatishka and Pirdopska rivers, which are also loaded with untreated domestic effluents and agricultural runoff (Gecheva et al. 2013). Consequently, Topolnitsa Reservoir serves as the final receiver for all the different contaminants in the river waters. However, there is no published data in the recent decades on the ecological status of the reservoir.

Common rudd, Scardinius erythrophthalmus (L.), is a cyprinid species that is present in many European rivers and lakes, and it is fished recreationally. A few reports have investigated metal concentrations and toxicity in different $S$. erythrophthalmus organs (Sikorska and Wolnicki 2006, Hanajavanit et al. 2008, Carassco et al. 2011, Djedjibegovic et al. 2012); however, general field or laboratory data on S. erythrophthalmus morphological and biochemical studies is quite scarce compared to that of other cyprinid fish. Therefore, the primary objective of the present study was to evaluate the current contamination status of Topolnitsa Reservoir by measuring $\mathrm{As}, \mathrm{Cd}, \mathrm{Cu}, \mathrm{Ni}, \mathrm{Pb}$, and $\mathrm{Zn}$ concentrations in surface water samples and in the liver of $S$. erythrophthalmus in three different seasons: spring, summer, and autumn. An additional aim was to study the fish response by examining liver morphological structure and the hepatic activities of $\mathrm{LDH}$, ALAT, and ASAT.

\section{Materials and methods}

The present study was conducted in Topolnitsa Reservoir (42 $\left.25^{\prime} 90^{\prime \prime} \mathrm{N}, 23^{\circ} 59^{\prime} 38^{\prime \prime} \mathrm{E}\right)$ in west central Bulgaria in 2012 in spring, summer, and autumn (Fig. 1). The reservoir is located about $63 \mathrm{~km}$ from Sofia, is one of the large artificial reservoirs in the country, and was built in the early 1960's across Topolnitsa River. During this period, one of the biggest copper ore extraction and smelting enterprises (Aurubis Bulgaria AD and Assarel-Medet JSC) was also built there. Reservoir waters are used to produce electricity through a hydropower turbine based on the reservoir wall, for agricultural irrigation, and recreational fishing.

Water samples for metal analysis were collected according to ISO 5667-6:2012 from the subsurface layer at a water depth of $1 \mathrm{~m}$ in triplicate in three season: spring, summer, and autumn in 2012. Water

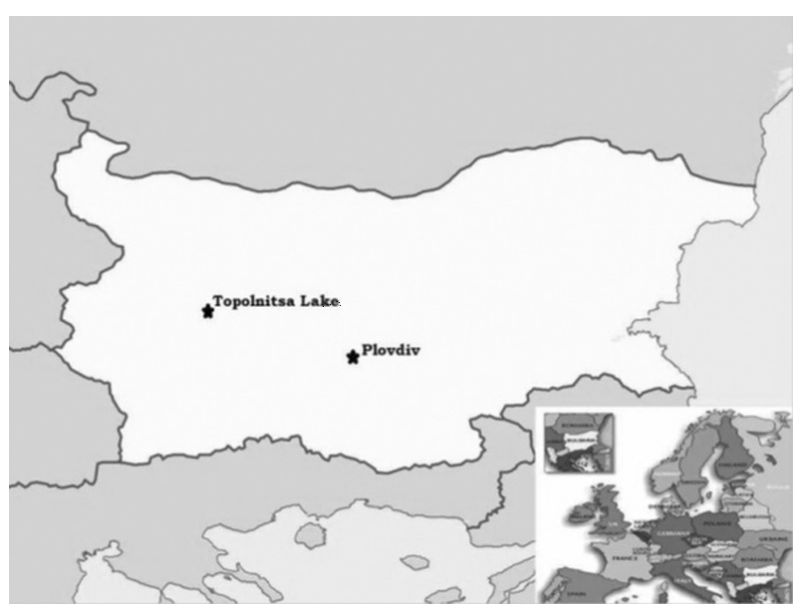

Figure 1. Location of Topolnitsa Reservoir in Bulgaria and the national Institute of Fisheries and Aquaculture in Plovdiv. 
$\mathrm{pH}$, temperature $\left({ }^{\circ} \mathrm{C}\right)$, dissolved oxygen $\left(\mathrm{mg} \mathrm{l}^{-1}\right)$ and conductivity $\left(\mu \mathrm{S} \mathrm{cm}^{-1}\right)$ were recorded simultaneously using a pH-meter (Multi 340i, WTW). Fish samples were collected according to the EMERGE protocol (Rosseland et al. 2003). In total 45 fish (15 in each season) were collected using a boat and fishing nets. Prior to dissection, fork length and weight were measured to the nearest $\mathrm{mm}$ and $\mathrm{g}(54 \pm 5.5 \mathrm{~g} ; 11.5 \pm$ $2.5 \mathrm{~cm}$ ). The livers were excised carefully and divided into three pieces for different analyses. For metal analysis, samples from each specimen were washed with distilled water, packed in clean, pre-marked polyethylene bags, held on ice, transported to the laboratory on the same day, and then deep frozen $\left(-25^{\circ} \mathrm{C}\right)$. For histological examinations, the samples were fixed in a $10 \%$ neutral buffered formaldehyde solution. For the enzymatic assay, the samples was snap frozen in liquid nitrogen. The reference materials were 15 healthy fish (five from each season) (56 $\pm 3.5 \mathrm{~g} ; 14 \pm 1.3 \mathrm{~cm}$ ) and water samples obtained from the national Institute of Fisheries and Aquaculture in Plovdiv, Bulgaria where fish are reared under strictly controlled, toxicant-free conditions. All experiments were conducted in accordance with national and international guidelines of the $\mathrm{Eu}$ ropean Parliament and the Council on the protection of animals used for scientific purposes (Directive 2010/63/EU).

All metal analyses were conducted at the accredited regional laboratory of the Executive Environment Agency in Plovdiv, Bulgaria. Chemicals were purchased from the Merck Group (Darmstadt, Germany); they were of analytical grade and Suprapur ${ }^{\circledR}$ quality. The laboratory equipment was made of Pyrex and high-density polyethylene. It was washed with $30 \% \mathrm{HNO}_{3}$, rinsed three times with deionized water, and allowed to dry in an oven at $105^{\circ} \mathrm{C}$ for $2 \mathrm{~h}$ (Ross, 1986). The analytical procedures and quality control were verified using replicate blanks and internationally certified reference materials for metals in waters, SRM 1643e (National 100 Institute of Standards and Technology, USA), and fish, DORM-3 (National Research Council Canada, Ottawa, Ontario, Canada), with every ten samples. Each sample was analyzed in triplicate. Replicate analysis of these reference materials showed good accuracy with recovery rates of 90 to $110 \%$.

Water chemistry analysis was conducted according to ISO 17294-2:2005. The metal content in the water was analyzed with an ISP-MS (Agilent 7500ce, Japan) and reported as $\mu \mathrm{g} \mathrm{l^{-1 }}$. The detection limit of

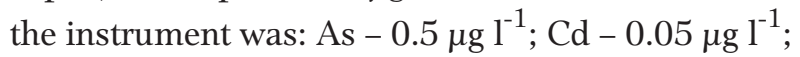
$\mathrm{Cu}-0.5 \mu \mathrm{gl}^{-1} ; \mathrm{Ni}-0.5 \mu \mathrm{gl}^{-1} ; \mathrm{Pb}-10 \mu \mathrm{g} \mathrm{l} \mathrm{l}^{-1}$, and $\mathrm{Zn}-$ $10 \mu \mathrm{g}^{-1}$. Prior to the actual assay, each liver sample was mineralized wet using a microwave digestion system (Milestone Ethos Plus, Italy). The digestion solution was prepared with $6 \mathrm{ml}$ of $65 \% \mathrm{HNO}_{3}$ and 2 $\mathrm{ml}$ of $30 \% \mathrm{H}_{2} \mathrm{O}_{2}$ at $200^{\circ} \mathrm{C}$. After mineralization, the samples were brought up to $25 \mathrm{ml}$ by adding ultra-pure water, and then they were analyzed for metals. The metal content was analyzed with an ICP-MS (Agilent 7500ce, Japan) and reported as $\mu \mathrm{g} \mathrm{kg}^{-1}$ wet weight. The detection limit of the instrument was: As $-10 \mu \mathrm{g} \mathrm{kg}^{-1}$; Cd $-1 \mu \mathrm{g} \mathrm{kg}^{-1} ; \mathrm{Cu}-10 \mu \mathrm{g} \mathrm{kg}^{-1}$; Ni - 10 $\mu \mathrm{g} \mathrm{kg}^{-1} ; \mathrm{Pb}-30 \mu \mathrm{g} \mathrm{kg}^{-1}$; and $\mathrm{Zn}-30 \mu \mathrm{g} \mathrm{kg}^{-1}$.

After fixation was complete (minimum time: 18-24 h) the samples were processed with a routine histological method (Humason 1979). The samples were sectioned to a thickness of 5-7 $\mu \mathrm{m}$ at different levels of the tissue using a semi-automated microtome (Leica RM2245), stained with conventional hematoxylin and eosin (H\&E) for histological examinations, prepared for light microscopy analysis (Roberts 2001), and photographed with a mounted digital camera. Multiple sections of each specimen were prepared and at least five slides each with three to four sections were examined and scored. The liver morphology of all the specimens, including that of the reference fish, was appraised individually and semi-quantitatively by using the grading system of Peebua et al. (2006), which we modified slightly. Histological change was evaluated and is presented as average values in percentages. Each grade represents specific histological characteristics and is categorized in terms of alterations to the hepatic architecture as follows: no histological alterations (-); mild histological alterations - 10-20\% - (+/-); moderate histological alterations $-30-50 \%-(+)$; severe histological alterations $-60-80 \%-(++)$; and 
very severe histological alterations - above $80 \%$ $(+++)$.

Livers (pooled wet mass of every two individuals) were rapidly thawed on ice and homogenized manually with a Potter Elvehjem homogenizer fitted with a Teflon pestle in chilled phosphate buffer $(50 \mathrm{mM}$, $300 \mathrm{mM} \mathrm{NaCl}, \mathrm{pH}$ 7.4). Homogenates were centrifuged at $9000 \mathrm{rpm}$ for $15 \mathrm{~min}$ in a cooling centrifuge (MPW $351 \mathrm{R}$ ) at $4^{\circ} \mathrm{C}$. The supernatant fractions were aliquoted, transferred in new Eppendorf tubes, and stored at $-80^{\circ} \mathrm{C}$ for enzyme assays. All biochemical assays were measured spectrophotometrically (Beckman Coulter Spectrophotometer DU 800) at $25^{\circ} \mathrm{C}$. Lactate dehydrogenase (LDH, E.C. 1.1.1.27) activity was assayed in $100 \mathrm{mM}$ potassium phosphate buffer ( $\mathrm{pH} 7.4$ ), $1 \mathrm{mM}$ pyruvate, and $0.14 \mathrm{mM}$ NADH lactate dehydrogenase and determined by measuring the amount of pyruvate consumed by NADH oxidation at $340 \mathrm{~nm}$ (backward reaction) according to Vassault (1983). Alanine aminotransferase (ALAT, E.C. 2.6.1.2) and aspartate aminotransferase (ASAT, E.C. 2.6.1.1) activities were determined using the method by Reitman and Frankel (1957) with commercially available kits (Merck). Briefly, ALAT was assayed in $1 \mathrm{ml}$ containing phosphate buffer (100 $\mu$ mol, $\mathrm{pH}$ 7.4), DL-alanine (100 $\mu \mathrm{mol}, \mathrm{pH}$ 7.4), L-ketoglutaric acid ( $2 \mu \mathrm{mol}, \mathrm{pH} 7.4$ ), and $0.2 \mathrm{ml}$ of freshly prepared homogenate. The reaction mixture was incubated at $37^{\circ} \mathrm{C}$ for $30 \mathrm{~min}$. ASAT was assayed in $1 \mathrm{ml}$ medium containing phosphate buffer (100 $\mu \mathrm{mol}, \mathrm{pH}$ 7.4), L-aspartic acid (100 $\mu \mathrm{mol}, \mathrm{pH}$ 7.4), L-ketoglutaric acid ( $2 \mu \mathrm{mol}, \mathrm{pH} 7.4)$, and $0.2 \mathrm{ml}$ of freshly prepared homogenate. The reaction mixture was incubated at $37^{\circ} \mathrm{C}$ for $1 \mathrm{~h}$. Protein levels were measured with the Bradford (1976) method with Coomassie Brilliant Blue G-250 using bovine serum albumin as the standard. The absorbance of samples was detected at $595 \mathrm{~nm}$ and expressed as $\mathrm{mg}$ protein per $\mathrm{ml} 150$ homogenate. One unit of $\mathrm{LDH}$ is defined as the amount of the enzyme that consumes $1 \mathrm{~mol} \mathrm{l}^{-1}$ of substrate or generates $1 \mathrm{~mol} \mathrm{l}^{-1}$ of product per min. The activity was expressed in international units per mg of protein $\left(\mathrm{U} \mathrm{mg}^{-1}\right)$. ALAT and ASAT activity were expressed in international units per $1\left(\mathrm{U} \mathrm{l}^{-1}\right)$.

Statistical analyses on metal concentrations in water and liver samples and enzyme activities was performed with the software program STATISTICA (version 7.0 for Windows, StatSoft, 2004). Differences between individual variables were tested for

Table 1

Topolnitsa Reservoir and reference site water quality parameters

\begin{tabular}{lcccccccc} 
& \multicolumn{3}{c}{ Topolnitsa Reservoir } & \multicolumn{3}{c}{ Reference site } \\
\cline { 2 - 9 } Parameters & Spring & Summer & Autumn & mean \pm SD & Spring & Summer & Autumn & mean \pm SD \\
\hline \hline pH & 8.2 & 6.5 & 7.3 & $7.3 \pm 0.7$ & 8 & 7.4 & 7.8 & $7.7 \pm 0.3$ \\
Temperature $\left({ }^{\circ} \mathrm{C}\right)$ & 7.1 & 19 & 5.2 & $10.4 \pm 6.1$ & 9 & 21.2 & 6.7 & $12.3 \pm 7.8$ \\
Conductivity $\left(\mu \mathrm{Sm}^{-1}\right)$ & 330 & 620 & 410 & $453.3 \pm 123$ & 410 & 580 & 350 & $447 \pm 119$ \\
Dissolved oxygen $\left(\mathrm{mg} \mathrm{l}^{-1}\right)$ & 8.5 & 7 & 9 & $8.2 \pm 0.9$ & 9 & 8.4 & 7.5 & $8.3 \pm 0.8$
\end{tabular}

Table 2

Metal (in $\mu \mathrm{g} \mathrm{l}^{-1} ; \pm \mathrm{SD}$ ) concentrations in Topolnitsa Reservoir water ( $\mathrm{n}=3$ in each season)

\begin{tabular}{lllll}
\hline \hline Element & Spring & Summer & Autumn & Bulgarian Legislation \\
\hline \hline $\mathrm{As}$ & $19.75^{\mathrm{c}} \pm 2.5$ & $13.2^{\mathrm{c}} \pm 1.3$ & $11.8^{\mathrm{c}} \pm 2.5$ & 10 \\
$\mathrm{Cd}$ & $0.63^{\mathrm{c}} \pm 0.1$ & $<0.05^{\mathrm{a}}$ & $<0.05^{\mathrm{a}}$ & 0.5 \\
$\mathrm{Cu}$ & $21^{\mathrm{c}} \pm 3.5$ & $45^{\mathrm{bc}} \pm 5$ & $11.7^{\mathrm{c}} \pm 2$ & 1 \\
$\mathrm{Ni}$ & $2.8 \pm 1$ & $1.2 \pm 0.5$ & $<0.05$ & 20 \\
$\mathrm{~Pb}$ & $<1^{\mathrm{a}}$ & $<1^{\mathrm{a}}$ & $<1^{\mathrm{a}}$ & 7 \\
$\mathrm{Zn}$ & $8.25^{\mathrm{c}} \pm 1.5$ & $8.4^{\mathrm{c}} \pm 1.3$ & $<1^{\mathrm{a}}$ & 8 \\
\hline \hline
\end{tabular}

${ }^{\mathrm{a}}$ less than the detection limit of the instrument, ${ }^{\mathrm{b}}$ metal concentrations differed significantly in other seasons, ${ }^{\mathrm{c}} \mathrm{metal}$ concentrations above the maximum permissible levels set by Bulgarian law 
significance using Student's t-test $(\mathrm{P}<0.05)$. Relationships between the contents of elements in the water and liver samples were tested using Pearson's Product-Moment correlation $(\mathrm{P}<0.05)$. The data are reported as mean $\pm \mathrm{SD}$.

\section{Results and discussion}

The general data regarding the Topolnitsa water is presented in Table 1, and metal concentrations are reported in Table 2. Metal concentrations in the Topolnitsa Reservoir surface waters varied among the three seasons. As and $\mathrm{Cu}$ concentrations were measured in the spring, summer, and autumn. In contrast, $\mathrm{Pb}$ concentrations dropped below the detection limit of the instrument in all three seasons. $\mathrm{Cd}$ concentrations were measured in the spring, but they were below detection limit of the instrument in the summer and autumn. $\mathrm{Ni}$ and $\mathrm{Zn}$ concentrations were measured in the spring and summer, but not in the autumn. We compared our results on metal concentrations in the Topolnitsa Reservoir surface waters with the maximum permissible levels set by Bulgarian regulations based on Directive 2000/60/EC. As and Cu concentrations in all three seasons were above the maximum permissible levels set by law. In addition, $\mathrm{Cd}$ concentrations in the spring and $\mathrm{Zn}$ concentrations in the spring and summer were also above the allowable limits. Ni concentrations were measured in the spring and summer, but they did not exceed the levels set by law. Therefore, we contend that contamination with these metals is because of intensive copper ore extraction and smelting processes in the region. In addition, other factors such as background metal levels, complex interactions between water, sediment, and biota, or other anthropogenic factors such as domestic sewage, industrial waste waters, and agricultural runoff could also influence metal concentrations in Topolnitsa Reservoir waters.

Metal concentrations in the liver of $S$. erythrophthalmus from Topolnitsa Reservoir are presented in Table 3. They were significantly higher than those in the water $(\mathrm{P}<0.05)$. Statistical analysis also showed that $\mathrm{As}$ and $\mathrm{Cu}$ concentrations in the water correlated to those in S. erythrophthalmus liver in all three seasons $(r=0.75$ for As and $r=0.83, \mathrm{P}<0.05)$. Metal concentrations in the reference fish liver were below the detection limit of the instrument. In contrast, those of the S. erythrophthalmus livers were similar among all three seasons but higher in the summer. However, only hepatic $\mathrm{Cu}$ and $\mathrm{Zn}$ concentrations were significantly higher in the summer than in the spring and autumn. Liver is a vulnerable organ during prolonged metal exposure from both waterborne and dietary sources, and metal levels in this organ represent the storage of metals from the water the fish species inhabited (Barone et al. 2013). Our results are in agreement of those of Poleksić et al. (2010) and Shinn et al. (2009), and confirmed that, as a parenchymal organ, the fish liver is a major depot for metal accumulation. Furthermore, we measured higher metal concentrations in $S$. erythrophthalmus liver in the summer. It is well known that the rates of metal uptake and

Table 3

Metal concentrations $\left(\mathrm{mg} \mathrm{kg}^{-1}\right.$ wet weight, $\pm \mathrm{SD}$ ) in the liver of $S$. erythrophthalmus from Topolnitsa Reservoir (n = 15 for each season)

\begin{tabular}{llll}
\hline \hline Element & Spring & Summer & Autumn \\
\hline \hline $\mathrm{As}$ & $1280 \pm 500$ & $1900 \pm 500$ & $1280 \pm 500$ \\
$\mathrm{Cd}$ & $1320 \pm 500$ & $1570 \pm 500$ & $1080 \pm 500$ \\
$\mathrm{Cu}$ & $8000^{\mathrm{a}} \pm 1200$ & $16800^{\mathrm{b}} \pm 5100$ & $15800^{\mathrm{b}} \pm 3100$ \\
$\mathrm{Ni}$ & $1360 \pm 400$ & $1520 \pm 300$ & $1800 \pm 500$ \\
$\mathrm{~Pb}$ & $1260 \pm 500$ & $1300 \pm 500$ & $1600 \pm 500$ \\
$\mathrm{Zn}$ & $17000^{\mathrm{a}} \pm 13200$ & $55900^{\mathrm{c}} \pm 5500$ & $26300^{\mathrm{b}} \pm 15400$ \\
\hline \hline
\end{tabular}

Values with different letter indexes differ significantly statistically $(\mathrm{P} \leq 0.05)$ 


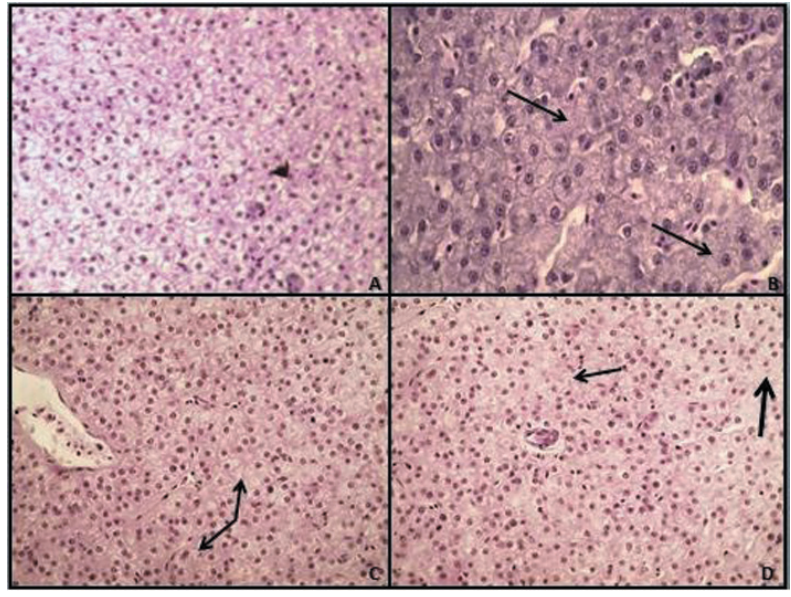

Figure 2. Histological alterations in the liver of S. erythrophthalmus from Topolnitsa Reservoir. Sections were stained with hematoxylin and eosin. Reference liver, $x 400$ (a), granular degeneration, $x 600$ (b), vacuolar degeneration, $x 400$ (c), necrobiosis, $x$ 400 (d).

accumulation increase with increasing temperature in ectothermic organisms (Sokolova and Lannig 2008). Similarly to Siscar et al. (2013), we also think that high metal concentrations in fish livers can be associated with processes of hematopoiesis, the antioxidant defense system, metallothione in synthesis, detoxification, and the excretion of metals.

Histological analysis demonstrated that the reference fish liver generally had a normal morphological structure with a typical parenchymatous appearance, and there were no pathological abnormalities (Figs. 2 and 3; Table 4). The parenchyma

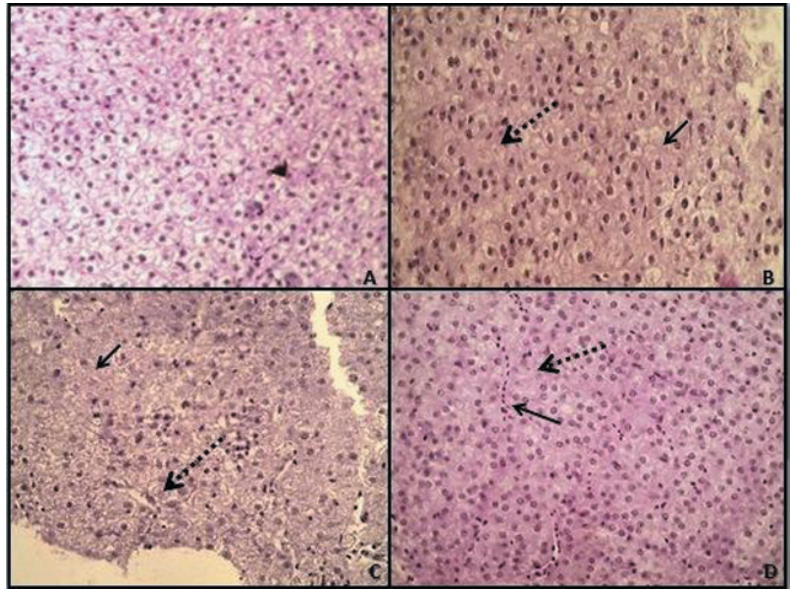

Figure 3. Histological alterations in liver of S. erythrophthalmus from Topolnitsa Reservoir. Sections were stained with hematoxylin and eosin. Reference liver, x 400 (a), necrobiosis (dashed arrow), granular degeneration (black arrow), x 400 (b), necrobiosis (dashed arrow), granular degeneration (black arrow), x 200 (c), necrobiosis (dashed arrow), hyperemia (black arrow), x 200 (d).

itself was primarily composed of hepatocytes typically with large central nuclei and homogenous cytoplasm. The hepatocytes were located among blood capillaries called sinusoids forming a cord-like structure known as hepatic cell cords. In contrast, we observed some serious histological alterations in the S. erythrophthalmus liver from Topolnitsa Reservoir (Figs. 2 and 3; Table 4). The results showed that the fish from Topolnitsa Reservoir had similar hepatic alterations in the spring, summer, and autumn, which were classified in the following main groups: 1) degenerative changes - granular, vacuolar, hydropic,

\section{Table 4}

Histological alterations in the liver of S. erythrophthalmus from Topolnitsa Reservoir

\begin{tabular}{|c|c|c|c|c|}
\hline Histological alteration & Spring & Summer & Autumn & Reference \\
\hline Granular degeneration & $+/-$ & + & + & $+/-$ \\
\hline Vacuolar degeneration & + & $+/-$ & $+/-$ & - \\
\hline Hydropic degeneration & $+/-$ & $+/-$ & - & - \\
\hline Fatty degeneration & $+/-$ & - & - & - \\
\hline \multicolumn{5}{|l|}{ Necrobiosis } \\
\hline karyopyknosis & $+/-$ & $+/-$ & - & - \\
\hline karyorrehis & $+/-$ & $+/-$ & - & - \\
\hline karyolysis & $+/-$ & - & $+/-$ & - \\
\hline Necrosis & - & - & - & - \\
\hline Hyperemia & - & $+/-$ & - & - \\
\hline
\end{tabular}

no histological alterations (-); mild histological alterations - 10-20\% - (+/-); moderate histological alterations - 30-50\% - (+); severe histological alterations $-60-80 \%-(++)$; and very severe histological alterations - above $80 \%-(+++)$ in the hepatic architecture 
and fatty degeneration; 2) necrotic changes (necrobiosis) - karyopyknosis, karyorrhexis, and karyolysis, and necrosis; 3) changes in the blood vessels - hyperemia in sinusoids and major blood vessels. In addition, results indicated a variation in the degree of expression of each histological alteration in S. erythrophthalmus in all three seasons (Table 4). In the spring, mild granular degeneration was mostly observed in the liver parenchyma. Vacuolar and hydropic degeneration were of moderate intensity. Fatty degeneration as a more severe hepatic alteration was found only in some individuals and in single hepatocytes to a mild degree. Necrobiosis was seen mainly in the hepatocytes. Karyopyknosis, karyorrhexis, and karyolysis were noted mostly to a mild degree. Only karyopyknosis was of moderate intensity. Necrosis in the liver parenchyma was detected, but only in isolated areas affecting a small number of hepatocytes (3-4 cells), and the extent of this alteration was mild. Hyperemia was not observed. During the summer season, the most common liver alteration observed was, once again, moderate granular degeneration. Vacuolar and hydropic degeneration were mild, and fatty degeneration was not noted. Necrotic changes in the

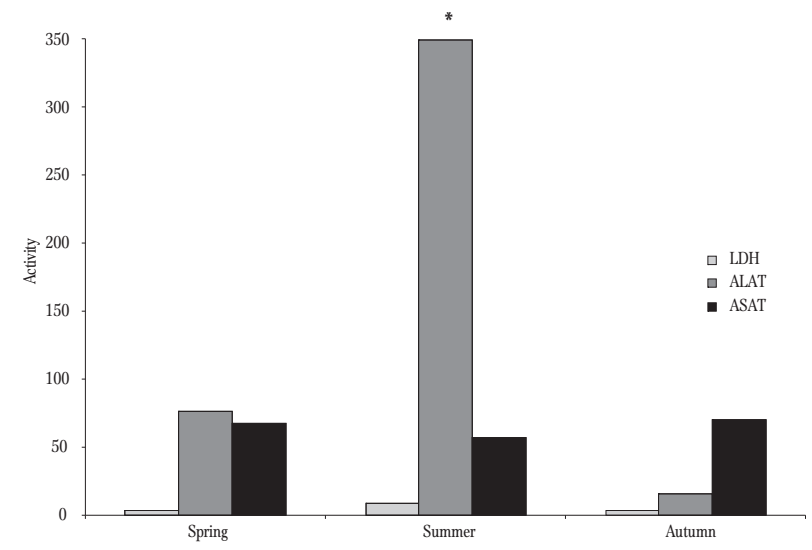

Figure 4. Activities of LDH, ALAT, and ASAT in the liver of $S$. erythrophthalmus from Topolnitsa Reservoir. The activity of LDH was expressed in international units per $\mathrm{mg}$ of protein $\left(\mathrm{U} \mathrm{mg}^{-1}\right)$, and activities of ALAT, and ASAT were expressed in international units per $1\left(\mathrm{Ul}^{-1}\right)$. * significant difference in ALAT activity between summer and the other two seasons. hepatocytes, including necrobiosis and necrosis, were always noted to a mild degree. Hyperemia was mild, both in the major blood vessels and in the sinusoids. In the autumn, the most frequently observed change in the hepatocytes was again moderate granular degeneration. Vacuolar degeneration was mild and found only in isolated hepatocytes. Hydropic and fatty degeneration was not detected. Necrotic changes and necrosis were mild. Hyperemia was not observed. Our histological results on the liver of $S$. erythrophthalmus from Topolnitsa Reservoir give us reason, similarly to Monteiro et al. (2005) and Rajeshkumar and Munuswamy (2011), to consider that these degenerative alterations (granular, vacuolar, hydropic, and fatty degeneration) are from biochemical disturbances, including the inhibition or activation of enzyme activity, changes in protein synthesis, impaired ion regulation, and the depletion of energy resources. Our results also correspond to those of Figuieredo-Fernandes et al. (2007), who suggest that high metal deposition in fish liver leads to the abnormalities that were observed in the hepatic structure and hepatocytes, and that can also lead to subsequent cell death. According Mela et al. (2007), the presence of necrotic areas is one of the

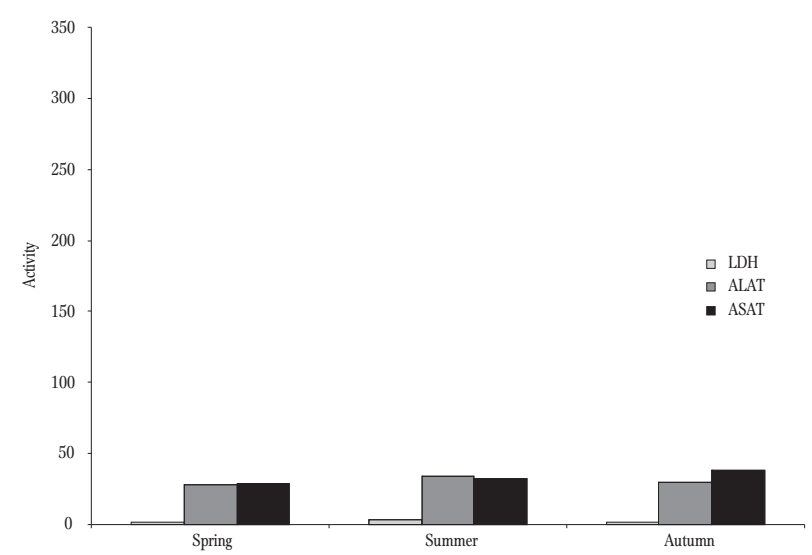

Figure 5. Activities of LDH, ALAT, and ASAT in reference $S$. erythrophthalmus liver. The activity of LDH was expressed in international units per mg of protein $\left(\mathrm{U} \mathrm{mg}^{-1}\right)$, and activities of ALAT, and ASAT were expressed in international units per $1\left(\mathrm{U} \mathrm{l}^{-1}\right)$. 
most serious alterations in liver structure that can occur under the influence of metals. Van Dyk et al. (2007) contends that liver hyperemia can lead to hepatic necrosis and atrophy. We agree with their statement, and we also believe that hyperemia can impact hepatic blood flow.

Hepatic LDH, ALAT, and ASAT activities in $S$. erythrophthalmus from Topolnitsa Reservoir and the reference fish are presented in figures 4 and 5. Overall, we established some variations in the enzymatic activities in the livers of $S$. erythrophthalmus from Topolnitsa Reservoir in all three seasons, but enzymatic activities were higher in the summer. However, only ALAT activity in the summer was significantly different than in the spring and autumn $(\mathrm{P}<0.05)$. In addition, ALAT and ASAT activities in the liver of $S$. erythrophthalmus from Topolnitsa Reservoir were enhanced significantly compared to those in the reference fish. There were no significant differences in LDH, ALAT, or ASAT activity in the reference fish among the seasons. Antioxidant defenses are commonly very well developed in the liver compared to other organs as a result of the central role this organ plays in detoxifying toxicants and processing many metabolic products for degradation (Avci et al. 2005). LDH is an enzyme located at a strategic point between glycolysis and the citric acid cycle that catalyzes the reversible oxidation of lactate to pyruvate in the terminal step of glycolysis (Reddy et al. 2011). According to Das et al. (2004), altered LDH activity is a marker of metabolic changes in fish such as a glucose shift toward the formation of lactate, hypoxic conditions, and tissue damage. ALAT and ASAT are liver specific enzymes that are a more sensitive measure of hepatotoxicity and histopathological changes and can be assessed within a shorter time (Balint et al. 1997). According to Abedi et al. (2013), inhibited or elevated enzyme activity compared to reference groups serves as a diagnostic tool in toxicology and is a good marker of metabolic changes in fish, i.e., hypoxic conditions, impaired antioxidant mechanisms, and cellular or tissue damage in fish. The hepatic damage and enzymatic changes we observed in the present study confirm this. Similarly to Regoli (1998), we also consider that the metal concentrations in the fish organs and tissues are likely to change with the seasons reflecting not only variability in environmental inputs but also changes in fish metabolism.

We conclude that the metal contamination of Topolnitsa Reservoir is chronic and its effects on $S$. erythrophthalmus include both histological and biochemical alterations. Thus, we consider that hepatic function is negatively affected and further investigations in this particular area are necessary. Moreover, our study offers the possibility of applying the methods used for the management of freshwater ecosystems. We also contend that the histological and biochemical biomarkers used are reliable and easy to use for monitoring waters and biota subjected to metal pollution.

Acknowledgments. The authors would like to thank everyone at the national regional laboratory who helped with the metal analyses and the Institute of Fisheries and Aquaculture for providing the reference fish and water samples.

Autor contributions. I.V., E.G. and I.I. designed the research, V.Y., S.S., T.V. and V. B. performed the research, I.V., E.G. and I.I. analyzed the data, V.Y. and S.S. wrote the paper..

\section{References}

Abedi Z., Hasantabar F., Mohammad K., Khalesi M.K., Babaei S. 2013 - Enzymatic activities in common carp, Cyprinus carpio influenced by sublethal concentrations of cadmium, lead, chromium - World J. Fish Marine Sci. 5: 144-151.

Avci A., Kaçmaz M., Durak I. 2005 - Peroxidation in muscle and liver tissues from fish in a contaminated river due to petroleum refinery industry - Ecotoxol. Environ. Saf. 6: 101-105.

Bálint T., Ferenczy J., Kátai F., Kiss I., Kráczer L., Kufcsák O., Láng G., Polyhos C., Szabó I., Szegletes T., Nemcsók J. 1997 - Similarities and differences between the massive eel (Anguilla anguilla L.) devastations that occurred in lake Balaton in 1991 and 1995 - Ecotoxol. Environ. Saf. 37: 17-23.

Barone G., Giacominelli-Stuffler R., Storelli M. 2013 - Comparative study on trace metal accumulation in the liver of 
two fish species (Torpedinidae): Concentration-size relationship - Ecotoxol. Envrion. Saf. 97: 73-77.

Bradford M.M. 1976 - A rapid and sensitive method for the quantification of microgram quantities of protein utilizing the principle of protein-dye binding - Analyt. Biochem. 72: 248-254.

Cao L., Huang W., Liu J., Yin X., Dou S. 2010 - Accumulation and oxidative stress biomarkers in Japanese flounder larvae and juveniles under chronic cadmium exposure Comp. Biochem. Physiol. C Toxicol. Pharmacol. 151: 386-392.

Carrasco L., Benejam L., Benito J., Bayona J.M., Díez S. 2011 - Methylmercury levels and bioaccumulation in the aquatic food web of a highly mercury-contaminated reservoir - Environ. Int. 37: 1213-1218.

Chahid A., Hilali M., Benlhachimi A., Bouzid T. 2014 - Contents of cadmium, mercury and lead in fish from the Atlantic sea (Morocco) determined by atomic absorption spectrometry - Food Chem. 147: 357-360.

Das P.C., Ayyappan S., Jena J.K., Das B.K. 2004 - Acute toxicity of ammonia and its sub-lethal effects on selected haematological and enzymatic parameters of mrigal, Cirrhinus mrigala (Hamilton) - Aquacult. Res. 35: 134-143.

Djedjibegovic J., Larssen T., Skrbo A., Marjanovi A., Sober M. 2012 - Contents of cadmium, copper, mercury and lead in fish from the Neretva river (Bosnia and Herzegovina) determined by inductively coupled plasma mass spectrometry (ICP-MS) - Food Chem. 131: 469-476.

Directive 2010/63/EU of the European parliament and of the council of 22 September 2010 on the protection of animals used for scientific purposes.

Directive 2013/39/EU of the European parliament and of the council of 12 August 2013 amending Directives 2000/60/EC and 2008/105/EC as regards priority substances in the field of water policy.

Figueiredo-Fernandes A., Ferreira-Cardoso J.V., Garcia-Santos S., Monteiro S.M., Carrola J., Matos P., Fontaínhas-Fernandes A. 2007 - Histopathological changes in liver and gill epithelium of Nile tilapia, Oreochromis niloticus, exposed to waterborne copper Pesq. Vet. Bras. 27: 103-109.

Gecheva G., Yurukova L., Cesa M., Cheshmedjiev S. 2013 Monitoring of aquatic mosses and sediments: a case study in contaminated rivers, Bulgaria 2013 - Plant Biosystems Published online: 12 Nov 2013.

Hanajavanit C., Bermingham M., Mulcahy M.F. 2008 - Epidemiology of squamous cell carcinomas in rudd Scardinius eryrthophtalmus, from SE Ireland - Dis. Aquat. Org. 80: 145-156.

Hansen B.A., Romma S., Garmo O.A., Olsvik P.A., Andersen R.A. 2006 - Antioxidative stress proteins and their gene expression in brown trout (Salmo trutta) from three rivers with different heavy metal levels - Comp. Biochem. Physiol. C Toxicol. Pharmacol. 143: 263-274.

Humason G.L. 1979 - Animal Tissue Techniques, 4th ed. W.H. Freeman and Company, San Francisco, CA, USA, $661 \mathrm{p}$.

ISO 5667-4: 1987 - Water quality - Sampling - Part 4: Sampling Guidance on sampling from lakes, natural and man-made.

ISO 17294-2: 2003 - Water Quality. Application of Inductively Coupled Plasma Mass Spectrometry (ICP-MS) Part 2: Determination of 62 Elements.

Majnoni F., Mansouri B., Rezaei M., Hamidian A.H. 2014 Metal concentrations in tissues of common carp, Cyprinus carpio, and silver carp, Hyophtalmichtys molitrix from the Zarivar Wetland in Western Iran Arch. Pol. Fish. 2: 11-18.

Mela M., Randi M.A.F., Ventura D.F., Carvalho C.E.V., Pelletier E., Oliveira Ribeiro C.A. 2007 - Effects of dietary methylmercury on liver and kidney histology in the neotropical fish Hoplias malabaricus - Ecotoxol. Environ. Saf. 68: 426-435.

Mohammadi M., Sary A.A., Khodadadi M. 2011 - Determination of heavy metals in two barbs, Barbus grypus and Barbus xanthopterus in Karoon and Dez Rivers, Khoozestan, Iran - Bull. Environ. Contam. Toxicol. 87: 158-162.

Monteiro S.M., Mancera J.M., Fontaínhas-Fernandes A., Sousa M. 2005 - Copper induced alterations of biochemical parameters in the gill and plasma of Oreochromis niloticus - Comp. Biochem. Physiol. C Toxicol. Pharmacol. 141: 375-383.

Peebua P., Kruatrachuea M., Pokethitiyooka P., Kosiyachindaa P. 2006 - Histological effects of contaminated sediments in Mae Klong River tributaries, Thailand, on Nile tilapia, Oreochromis niloticus - Sci. Asia 32: 143-150.

Pokorska K., Protasowicki M., Bernat K., Kucharczyk M. 2012 - Content of metals in flounder, Platichthy sflesus L., and Baltic herring, Clupea harengus membras L., from the southern Baltic Sea - Arch. Pol. Fish. 20: 51-53.

Poleksić V., Lenhardt M., Jaric I., Djordjevic D., Gacic Z., Cvijanovic G., Raskovic B. 2010 - Liver, gills, and skin histopathology and heavy metal content of the Danube sterlet (Acipenser ruthenus Linnaeus, 1758) - Environ. Toxicol. Chem. 29: 515-521.

Rajeshkumar S., Munuswamy N. 2011 - Impact of metals on histopathology and expression of HSP 70 in different tissues of Milk fish (Chanos chanos) of Kaattuppalli Island, South East Coast, India - Chemosphere 83: 415-421.

Reddy Janardana S., Reddy Kiran T., Redyy C.T. 2011 - Influence of heavy metals on biochemical and metabolic biomarkers of Indian major carp, Labeo rohita - Int. Quarterly J. Life Sci. 6: 167-173. 
Reitman S., Frankel S. 1957 - A colorimetric method for the determination of serum glutamic oxaloacetic and glutamic pyruvic transaminases - Am. J. Clin. Pathol. 28: 56-63.

Regoli F. 1998 - Trace metals and antioxidant enzymes in gills and digestive gland of the Mediterranean mussel Mytilus galloprovincialis - Arch. Environ. Contam. Toxicol. 34: 48-63.

Roberts R.J. 2001 - Fish Pathology, third ed. - W.B. Saunders, Philadelphia, PA, 462 p.

Rosseland B.O., Massabuau J.C., Grimalt J., Hofer R., Lackner R., Raddum G., Rognerud S., Vives I. 2003 Fish Ecotoxicology: European Mountain Lake Ecosystems Regionalisation, DiaGnostic and Socio-economic Evaluation (EMERGE). Fish Sampling Manual for Live Fish - Norwegian Institute for Water Research (NIVA), Oslo, Norway, 7 p.

Shinn C., Dauba F., Grenouillet G., Guenard G., Lek S. 2009 Temporal variation of heavy metal contamination in fish of the river lot in southern France - Ecotoxol. Environ. Saf. 72: 1957-1965.
Sikorska J., Wolnicki J. 2006 - Cadmium toxicity to rudd (Scardinius erythrophtalmus (L.)) larvae after short-term exposure - Arch. Pol. Fish. 14: 15-27.

Siscar R., Koenig S., Torreblanca A., Solé M. 2013 - The role of metallothionein and selenium in metal detoxification in the liver of deep-sea fish from the NW Mediterranean Sea - Sci. Tot. Environ. 466-467: 898-905.

Song Y., Salbu B., Sørlie Heier L., Teien H.C., Lind O.C., Oughton D., Petersen K., Rosseland, B.O., Skipperud L., Tollefsen K.E. 2012 - Early stress responses in Atlantic salmon (Salmo salar) exposed to environmentally relevant concentrations of uranium - Aquat. Toxicol. 112-113: 62-71.

Sokolova I.M., Lannig G. 2008 - Interactive effects of metal pollution and temperature on metabolism in aquatic ectotherms: implications of global climate change - Clim. Res. 37: 181-201.

Van Dyk J.C., Pieterse G.M., Vuren J.H.J. 2007 - Histological changes in the liver of Oreochromi smossambicus (Cichlidae) after exposure to cadmium and zinc Ecotoxol. Environ. Saf. 66: 432-440.

Vassault A.1983 - Methods of Enzymatic Analysis - Academic Press, New York: 118-126 p. 